Society \& Natural Resources

\title{
Actor-Based Design of a Management System for the Elephant Marsh Fishery in Malawi
}

\section{Ishmael B. M. Kosamu, Wouter T. de Groot \& Patrick S. Kambewa}

To cite this article: Ishmael B. M. Kosamu, Wouter T. de Groot \& Patrick S. Kambewa (2016): Actor-Based Design of a Management System for the Elephant Marsh Fishery in Malawi, Society \& Natural Resources, DOI: 10.1080/08941920.2016.1209604

To link to this article: http://dx.doi.org/10.1080/08941920.2016.1209604

Published online: 17 Aug 2016.

Submit your article to this journal $₫$

View related articles $\longleftarrow$

View Crossmark data ¿ 


\title{
Actor-Based Design of a Management System for the Elephant Marsh Fishery in Malawi
}

\author{
Ishmael B. M. Kosamu ${ }^{\mathrm{a}, \mathrm{b}}$, Wouter T. de Groot ${ }^{\mathrm{b}, \mathrm{c}}$, and Patrick S. Kambewa ${ }^{\mathrm{d}}$ \\ aDepartment of Physics and Biochemical Sciences, University of Malawi, Blantyre, Malawi; 'bnstitute of \\ Environmental Sciences (CML), Leiden University, Leiden, The Netherlands; Institute for Science and \\ Innovation Studies (ISIS), Radboud University, Nijmegen, The Netherlands; 'Department of Economics, \\ University of Malawi, Zomba, Malawi
}

\begin{abstract}
In Malawi, fishing community user groups known as beach village committees, traditional chiefs, government officers, and fishers are the key players in fisheries management. Fish catch trends at the Elephant Marsh Fishery in southern Malawi are declining. Based on interviews and participant observation, this article uses an actor-based framework (known as Action-in-Context) to unveil the issues that are crucial in devising a sustainable governance system for the fishery. We establish and propose that the key social variables for the design of a three-pillared (locally based, weak, and amorphous) resilient institution for sustainability of the Elephant Marsh Fishery are (i) the social reputation of the leaders of local fishery institutions (beach village committee leaders), and (ii) the power dynamics between traditional chiefs and these local fishery leaders. We end the article by exploring the implications of the findings on the sustainability of the fishery under rising resource pressure.
\end{abstract}

\section{ARTICLE HISTORY}

Received 10 March 2015

Accepted 20 June 2016

\section{KEYWORDS}

Action-in-Context; Elephant Marsh; governance; local institutions; small-scale fisheries; sustainability

The Elephant Marsh, a wetland in the southern part of Malawi, is important for small-scale fisheries (SSF). The wetland is located on the East African Rift Valley floor and covers an average area of about $600 \mathrm{~km}^{2}$, varying between $2,700 \mathrm{~km}^{2}$ in the wet season and $500 \mathrm{~km}^{2}$ in the dry season. The marsh is fed by the Shire River, the only outlet of Lake Malawi, which flows through it in a southerly direction before joining the Zambezi River in Mozambique. The marsh has relatively grassy margins but the bulk of its surface is formed by a mosaic of rooted swamp vegetation (sudd), floating vegetation, and open water. The Elephant Marsh is home to several species of fish, out of which Clarias gariepinus (locally known as mlamba), Oreochromis mossambicus (makakana or mphende), Oreochromis placidus (makumba), and Barbus ssp. (matemba) comprise more than $90 \%$ of the commercial catch (World Bank 2010). The annual fish production from around the Elephant Marsh has been estimated at about 8,500 tonnes. There are no recent scientific data on the trends of fisheries exploitation at the Elephant Marsh, but fishers generally feel the catch per unit effort (CPUE) is slowly decreasing (Kosamu 2014). Based on a 2014 survey by Malawi's Department of Fisheries (DoF) there are about 1,500 fishers at the Elephant Marsh. 
The Elephant Marsh Fishery is mainly guided by customary law through village chiefs who receive their mandate through inheritance, and is managed by user groups called "Beach Village Committees" (BVCs), which are headed by chairpersons (BVC Chairs). Village chiefs are given ex officio (nonvoting) roles as patrons of the BVCs (Russell and Dobson 2011). The term "beach" stands for a fish landing site: sandy or swampy (as at the Elephant Marsh). They are connected to one fishing village each. The Beach Chair and the other members of the BVC (usually composed of 10 office bearers) are elected directly into their positions through local democracy at a village meeting for a 2-year renewable term. Villagers eligible to vote are mainly those who are involved in fishing activities, such as fishers and fish traders. At the Elephant Marsh Fishery, fish traders are also locally known as angoni, broadly meaning foreigner and, specifically for this fishery, someone from outside the circle of the fishing villages at the Elephant Marsh (although Angoni also refers to an ethnic group in Malawi), and are not allowed to fish.

The concept of BVCs was introduced in Malawi in 1991 as a government initiative under the Participatory Fisheries Management Programme (PFMP) in response to declining fish catches at Lake Malombe and the Upper Shire River (Lewins et al. 2014). Since then BVCs have been adopted at the national level and supported by the National Fisheries and Aquaculture Policy (NFAP) (Government of Malawi 2001) as a participatory link between the Department of Fisheries (DoF) and the fishing communities.

Although the Elephant Marsh can be characterized as a single ecosystem, the mosaic landscape has led to fragmentation of the open water into several smaller "lakes," which are managed independently at the fishing village (beach) level. Currently there is no overall fisheries management association to coordinate the operations of the BVCs (Kosamu 2014). Bavinck (2005) reported that the actions of fishers in one part of such SSF systems often affect those of others in a different location of the same system. Indeed, migration is a common feature among fishers at the Elephant Marsh. Fishers periodically migrate to beaches where the catch is better than their home village, often for short stays with no intentions of permanent shift. The phenomenon has also been observed in other parts of Africa (Nunan 2010).

Studies on the Elephant Marsh fishery are limited. Evidence from a study by Kosamu et al. (2012) shows that the locally based management system at Elephant Marsh is working well. These findings are consistent with Bavinck's (1996) assertion that local decisionmaking structures in fishing communities are capable of implementing regulatory actions toward what is perceived as a common good. However, due to background developments such as population growth, rural poverty, climate change, and market forces, the exploitation pressure on the already declining fish catches at the Elephant Marsh Fishery is likely to increase, and achieving sustainability in the near future may require more resilient institutions than those that are now at work.

Another study by Kosamu (2014) reveals that the quality of leadership of the local fisheries committee (BVC Chairs) seems to be a prime factor for a well-managed Elephant Marsh Fishery. With Kosamu's (2014) revelation as a premise, this article first addresses issues that relate to the actions and motivations of fishers at the Elephant Marsh Fishery and then moves on with a similar analysis to the other key actors such as BVC Chairs, village leaders, and government fisheries officers. The article aims at unveiling a short-term management design for the Elephant Marsh Fishery specifically and a type of thinking that maybe fruitful to institutional science in general. 


\section{Methodology}

\section{Methodological Framework}

In this article we follow an actor-based approach (as opposed to a more systems-oriented approach) that identifies the roles of all actors connected to the fishery (e.g., fishers or government officers) and the institutions that underlie the action of the actors (Hobbes et al. 2007). This is consonant with our desire to trace social causation, because actors, not systems, are the social entities that can act and thereby effect changes (Anderies, Janssen, and Ostrom 2004). The approach does not deny the importance of social systems. Obviously, as Latour (2005) puts it, the social connections that an actor has with different networks determine what the actor is, wants, and can do. The social networks have actually been found to influence actors' behavior in natural resources management (Bodin and Crona 2009). In this article, we use the "Action-in-Context" framework (AiC) as devised by De Groot (1992) to identify all the major actors, their potential to act (comprising their active capacity and motivation to act), and their actions' causal linkages before identifying the overall patterns of social causation that emerge. Action-in-Context (AiC) is an actorbased framework inspired by such authors as Vayda (1983), Vayda and Walters (1999), and Elster (1989), designed to facilitate the tracing of multi-actor and multilevel social causation.

The domain of AiC can be defined as "sufficiently deliberative action." This then excludes habitual or purely emotional or physical behaviors, as well as people's relatively deep "life choices" or commitments, which are shaped by an actor's values (Song and Chuenpagdee 2011). Thus, our assumption in this study is that small-scale fisheries management is sufficiently deliberative to allow for valid description in a broad and culturally sensitive rational choice approach. This is comparable to, for instance, Ostrom's (1990) application of broad rational choice to resource management where actors collectively achieve intended results through constrained purposeful action by building conditions for reciprocity, trust, and reputation that help to overcome strong temptations of shortterm self-interest of the individual actors (Ostrom 1998a). The rational choice approach asserts that all individual actors are able to learn rules and norms, and how to craft new rules to improve an achieved outcome (which in our case is an improved management system for the Elephant Marsh Fishery).

The core element of $\mathrm{AiC}$ is a triangular causal structure that expresses that in order to act, the actor needs both the motivation ("desire," "will," etc.) and the option ("opportunity," "autonomy," "power," etc.) to do so. In this article we look at power as a relational construct and define it as the level of cost incurred if one unilaterally withdraws from a relationship (Crona and Bodin 2010). Thus, a low cost of withdrawal means high power and vice versa. In Figure 1 the triangular causal structure of the actor, action, and implementable options and motivations is illustrated with terms added from our fisheries case at the Elephant Marsh. Typically for AiC, implementable options and motivations are depicted as separate from each other, despite the fact that on a deeper level they are interdependent. For instance, people do not usually continue to have desires for what they know they can never get (options), while on the other hand persistent desires can build capacity on a longer run. Thus, AiC enables clear and comprehensive causal mapping of ongoing interactions, without denying that more interpretative methods might be needed to understand longer-term change. 


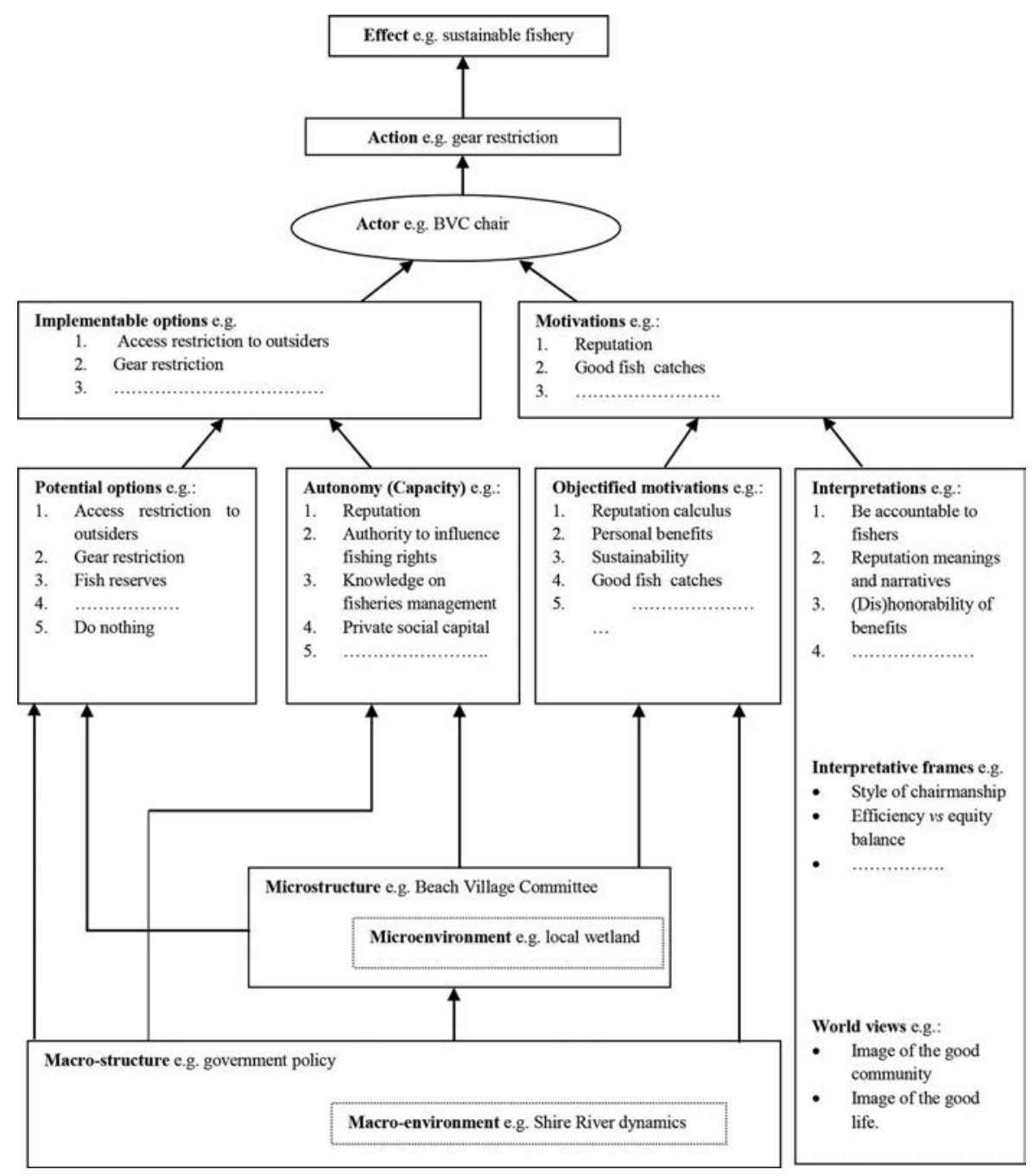

Figure 1. The structure of AiC "deeper analysis" with a few items from the study area filled in. The BVC Chair's action of gear restriction is the explanandum from which the analysis works its way downward. Arrows indicate the causal direction.

From the causal triangle onward, AiC proceeds in two analytical directions. The first is depicted in Figure 1, and called "deeper analysis," connecting as it does the actor's implementable options and motivations to their underlying social phenomena. In Figure 1, for instance, the BVC Chair's motivation to maintain his social reputation embeds his actions in the BVC ("microstructure"). The "implementable options" of the actor are built from "autonomy" or "capacity" composed of institutions, rules, financial or private social capital (personal benefits that actors derive from their social networks) (Kostova and Roth 2003), and "potential options." The difference between "potential options" and "implementable options" lies in what the actor can really do in the active world as opposed to what the actor could do if presented with greater capacities. "Motivations" are all aspects of the options under normative consideration by the actors in their choice of action. They can be separated analytically as "objectified motivations" and "interpretations." "Objectified 
motivations" are the quantifiable demerits of the action, for example, in terms of money or calories. Actions of decision makers in fisheries management are often influenced by such quantitative motivations, but on the other hand, more culturally embedded qualifications of costs and benefits can be important too; these are called "interpretations" in AiC. "Interpretations" relate to the Simon, Smithburg, and Thompson (1958) overview of human motivations, which are material inducements (money or goods); opportunities for distinction, prestige, and personal power; desirable conditions of work, such as cleanliness; pride in workmanship; service for family or others; patriotism or religious feeling; personal comfort and satisfaction in social relationships; conformity to habitual practices and attitudes; and a feeling of participation in important events. These basic individual motivations and values have also been reported by Schwartz et al. (2012) in a more detailed assessment.

The second analytical direction for tracing of causal linkages in AiC connects the actionto-be explained to actions of other actors, specifying the "actor's field" that links the actor (e.g., BVC chair) to secondary actors such as the village chief, fishers, and government officers (Figure 2), through intermediary actions. The BVC Chair's actions are influenced by other actors that act upon the motivations or options for a particular action. When identified, these "actors of influence," such as the village chief or government, are referred to as secondary actors. (Note that what is called primary, secondary, etc. here is only a matter of counting, not denoting empirical or normative importance.) From there on, it is easy to identify causal linkages with the next, tertiary layer of "actors of influence."

Thus, we see that the actor's field concept deeply differs from social networks that appear to be the only inter-actors concept guiding the social sciences. Broadly put, social networks are structures related to how actors shape institutions (collective action), while actors' fields describe how institutions shape the actions of the actors (Hobbes et al. 2007).

\section{Data Collection and Analysis}

Data collection was undertaken between March and June 2014. Interviews, focus-group discussions, and observations were done at 24 fishing villages at the Elephant Marsh with fishers $(n=240)$, BVC Chairs $(n=24)$, village leaders $(n=24)$, fisheries officers $(n=6)$, and district and national fisheries officials $(n=10)$. Secondary data were obtained from such sources as government databases, reports, journals, and Internet articles.

Some of the questions for each of the four key actors at the Elephant Marsh Fishery included: What are the actions of the key actor? What capacities and motivations (costs and benefits/incentives) explain these actions? Which institutions or structures underlie the key actor's motivations and capacities? How are the actions of the key actor influenced by the other key actors? What are the capacities and motivations of these other key actors who have an influence on the actions of the key actor in question? What are the main social causalities, dynamics, and mechanisms among these key actors? A social causation map (Glaser 2006) emerging from answers to these questions helped in tracing the key factors and actors that are essential in crafting institutions that could be central in achieving sustainability of the Elephant Marsh Fishery under increasing pressure but that also help institutional designers in small-scale fisheries. This is particularly important because, as Ostrom (1992) highlights, an institution is "the set of rules-in-use by a set of individuals to self-organize repetitive activities that produce outcomes affecting those individuals and potentially affecting others" (19). 


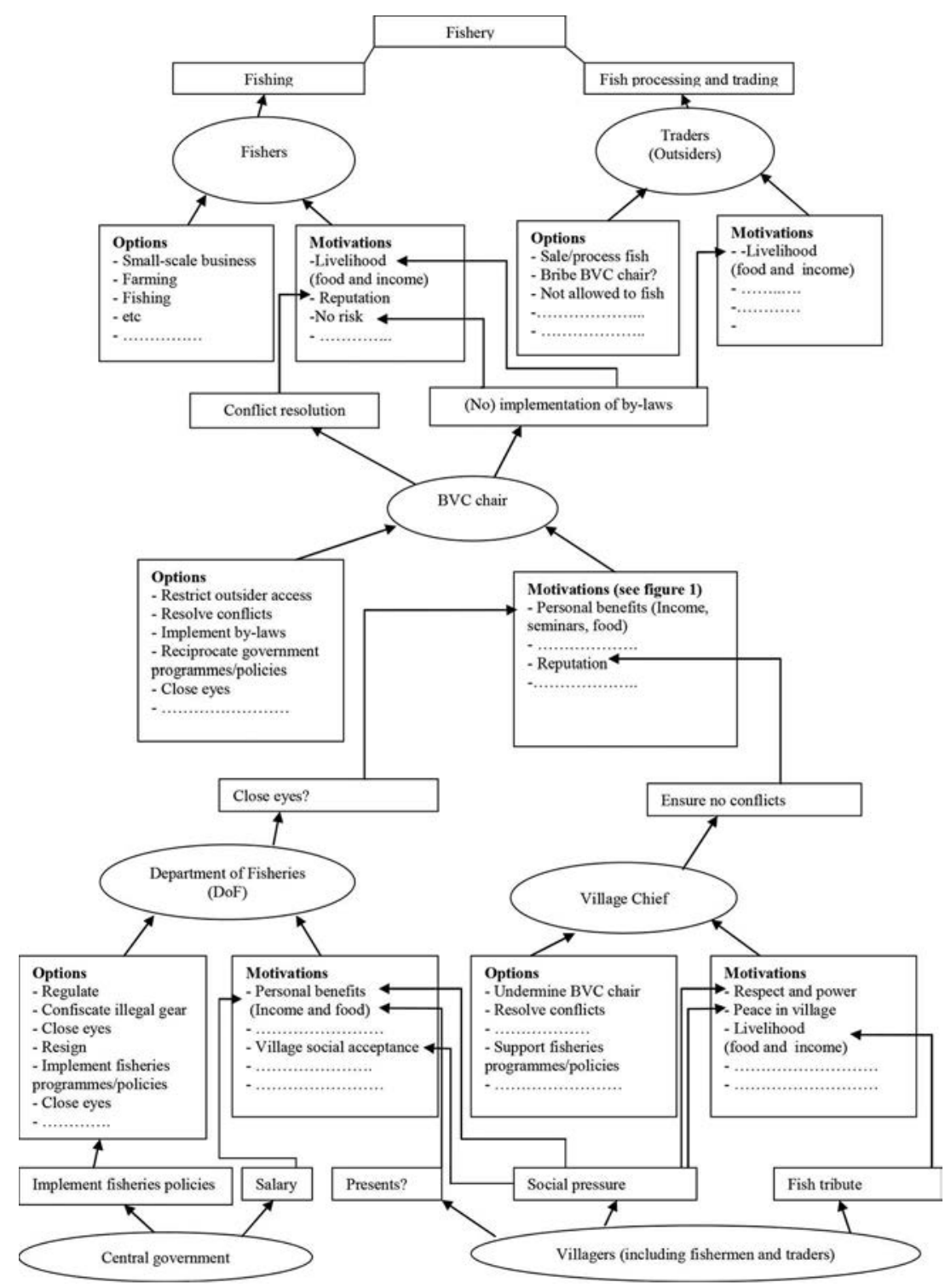

Figure 2. Summary of an actors' field for the Elephant Marsh Fishery. Below each actor category, the boxes indicate the options and motivations leading to the actor's actual action. Actors are linked through actions that influence options and/or motivations of other actors.

As the answers to these questions were sought, it was also important to bear in mind that some of the pressures that exist at the Elephant Marsh may require some ecological thinking, too. Our focus on sociocausal linkages had a reason: Any solution (whether ecologically or socially based) requires social embedding (Cleaver 2002) to work at all.

The interviews were guided by AiC schemas and the concept of "sustainability," which was discussed in terms of catches going down persistently or fishers leaving the beach for other beaches. Interview responses were progressively synthesized into AiC schema during field data collection. Participant observation helped verify interactions between actors, the 
market prices, and size of catches, main fish species, and the legality of the fishing gear used, among other attributes. The resulting AiC schemas were then progressively interpreted and synthesized into a number of narratives that focused on key themes. For an example of a characteristic AiC schema result, see Figure 2, which takes a BVC Chair as a primary actor and shows how the motivations and options of other key actors influence the BVC Chair's actions in the management of the Elephant Marsh Fishery.

In the presentation of the study findings, we focus on the resultant narrative themes, which are organized based on the main actors as highlighted in Figure 2.

\section{Results}

This section reports on the causal narratives (themes) that emerged from the AiC analysis and starts off with the fishers.

\section{Livelihood Support and Reputation Motivate the Fisher}

This study found that most of the families (>70\%) at the Elephant Marsh are poor and depend on fish and subsistence wetland agriculture for their livelihood. Table 1 summarizes the basic cost and benefits at the Elephant Marsh. It is evident from the table that the returns to labor of specialized fishing are much higher (three to four times) than those of specialized wetland rice farming. Moreover, rice farming is feasible only in one season. This is an important background for interpretation of our fisheries data. People do not have access to remunerative options besides fisheries, for instance, and reputation in fishing activities corresponds to a large extent to reputation at the village level ("interpretations" in Figure 1). It is also interesting to note that an annual net income of roughly US $\$ 3,000$ (Table 1) for an average fishing household of five persons (National Statistics Office (NSO) 2008) translates to US\$1.6 per day, which is just below the new global poverty line recommendation of US $\$ 1.9$ (World Bank 2015).

Fishers indicated that being able to support a family with food and basic income ("objectified motivations" in Figure 1) brings pride and social acceptance in the village ("interpretations"). Social reputation is also enhanced by good citizenship as displayed,

Table 1. Return to labor (US\$ per working day) for the two main livelihood activities at the Elephant Marsh, using estimates of the most commonly occurring cost and benefit figures.

\begin{tabular}{|c|c|c|}
\hline Item & Wetland rice farming & Fishing \\
\hline 1. Labour investment & 70 days/ha/yr & 300 days/yr \\
\hline \multirow[t]{2}{*}{ 2. Inputs } & $\begin{array}{l}\text { (i) Rice seeds: } 40 \mathrm{~kg} / \mathrm{ha} \times \\
\text { US\$0.7/kg = US\$28 } \\
\text { (ii) Fertilizer (urea): } 50 \mathrm{~kg} / \mathrm{ha} \times \\
\text { US\$0.8/kg = US\$40 }\end{array}$ & $\begin{array}{l}\text { (i) Cost of a dugout canoe }=\text { US\$177 every } \\
7 \text { years }=\text { US } \$ 25 / \mathrm{yr} \\
\text { (ii) Fishing licence fee }=\text { US\$0.9/yr }\end{array}$ \\
\hline & Total inputs $=$ US $\$ 68 / y r$ & $\begin{array}{l}\text { (iii) Gill net }(100 \mathrm{~m})=\text { US\$0.4 } \times 100=\text { US\$ } \$ 0 / y r \\
\text { Total inputs }=\text { US } \$ 66 / y r\end{array}$ \\
\hline $\begin{array}{l}\text { 3. Annual } \\
\text { harvest/catch }\end{array}$ & $1,000 \mathrm{~kg} / \mathrm{ha} / \mathrm{yr}$ & $\begin{array}{l}10 \mathrm{~kg} \text { per day ( } 11 \mathrm{~kg} \text { is usually caught and about } 1 \mathrm{~kg} \text { is } \\
\text { given to village chief as tribute) } \times 300 \text { days } / \mathrm{yr}=3,000 \mathrm{~kg} / \mathrm{yr}\end{array}$ \\
\hline 4. Market price & US\$0.3 / kg & US\$1.12 /kg \\
\hline 5. Gross income & $1,000 \times$ US\$0.3 $=300$ US\$/yr & $3,000 \times$ US\$1.12=3,360 US\$/yr \\
\hline 6. Net income & US\$238/yr & U\$3,294/yr \\
\hline 7. Return to labor & US\$3/working day & US\$11/working day \\
\hline
\end{tabular}

Note. The estimates are based on assumption of 8 working hours per day, 300 working days per year (i.e., no sickness or other major problems), and that there no other economic activities for the rest of the year. 
for instance, by reciprocating trust, participating in communal work, funerals, and other activities, and refraining from illegal actions such as breaking fisheries bylaws.

\section{Reputation is the Key for the BVC Chair}

The capacity and motivation of BVC chairs to implement the local fisheries rules are pivotal for the fishery at the Elephant Marsh to work. In this section, we first discuss the rules, the BVC Chair's motivations, and finally their implementation capacity. According to Ostrom (1992), rules work well when "every participant knows the rules, knows that others know the rules, and knows that others also know that the participant knows the rules" (20). The rulesin-use by the actors are therefore not always the written by-laws or indeed the legislative provisions or court regulations (Ostrom 1992) but self-modified versions of the written rules. In the same vein, some respondents lamented that social complexities at village level can make it difficult to impose sanctions against offending fishers, as narrated by one BVC Chair: "We wish we could confiscate gear but looking at our local situation [poverty in the village], we feel sorry and just forgive each other." In some cases implementation of the rules was lacking because of fear for cultural beliefs (witchcraft), as revealed from the following response: "This village is not united; if you offend someone [confiscate their fishing gear] they can 'create' crocodiles which can kill you when you go fishing."

When asked if BVC Chairs had the capacity to restrict the number of new (non-angoni) fishers coming to a beach, most respondents thought it is impossible to implement that provision. The BVC Chair at Mchachajemusi said: "It is possible to regulate fishing gear, regulate timing and to deny access to angoni, but new fishers from local villages are always welcome because in our culture it is a taboo to exclude own people. There is no way to keep these new fishers away. ... Not even the chief, the government, or the president can do that." The BVC chair at Chisamba, which is one of the beaches with good fish catches, indicated the beach had many fishers and new ones kept coming; the BVC counteracts this immigration pressure by implementing an annual semiclosed season between January 1 and March 31 during which it is strictly not allowed to use certain gear such as seine nets. The BVC Chair further suggested that in the future they may have to control how much each fisher catches, so that everyone has equal access.

Besides managing their own beaches, BVC Chairs also display a degree of interbeach coordination. With a focus on maintaining social order, BVC Chairs write transfer letters for outgoing fishers and demand the same from fishers coming to their beach. They also make phone calls to inform one another about troublesome fishers such as boat thieves. An example of sustainability-oriented coordination is that the beaches of Nsambokulira, Twaya, Bwemba, Chuluchamkango, and Mchachajemusi jointly maintain a ban on kumba nets (under-meshed gill nets originating from Mozambique). Indicative of the weak power of such agreements is that some beaches that are party to the agreement (like Bwemba and Twaya) are currently not implementing the ban.

From our analysis, at almost all beaches with good fish catches, the implementation of bylaws by the BVC Chair was adhered to. In the interviews, one BVC Chair attributed their capacity to manage beaches well to personal reputation: "When the affairs at the beach are being managed well, people give me a lot of respect." As Brondizio, Ostrom, and Young (2009) observe, personal reputation is a social capital, which is built through social networks by repeated trustworthy interactions between actors. The fungibility of this capital 
was noted, for example, in that with any failure of a BVC Chair to resolve conflicts or keep outsiders out, or if fishers move away from the beach due to low catches, the other villagers may consider that as a weakness and the BVC Chair may become a subject of village gossip, leading to overall loss of reputation. Thus, failure to implement bylaws invokes the breakdown of reputation, which then further reduces the BVC Chair's capacity to act.

When asked about how they resolve conflicts, all respondents (BVC Chairs, village chiefs, and fishers) said conflict resolution starts from the BVC Chair, who may refer more serious offenses to the village chief, police, or courts (in that order), depending on the gravity of an issue at hand. None of the respondents mentioned the Department of Fisheries (DoF) as a legitimate player in conflict resolution. Of course, the DoF with support from the chiefs has the legitimate power, for example, to seize illegal gear under sections 30 and 32 of the Fisheries Conservation and Management Act (FMCA) (Government of Malawi 1997), but the mandate to resolve conflicts and destroy seized items is vested in customary law and, if need be, the criminal law courts. Our analysis of conflict resolution revealed that while the BVC Chairs and village chiefs tend to be motivated to resolve the conflicts because they want to protect their reputation and possibly get some other benefits (e.g., fines), the motivation (both "objectified motivations" and "interpretations") of the police and courts is very weak because there is no direct incentive for them from the fishery.

All BVC Chairs in our sample acknowledged that the village chief is an important source of BVC Chair's power and legitimacy without whose support things fall apart. For example, we identified a case at one beach in which the chief did not want to support the BVC Chair and the tension resulted in a physical fight, finally adjudicated by court. The BVC Chair of the concerned beach had this to say:

Some chiefs are just difficult for no reason. Our chief here was threatening me that I had no power to tell the fishers what they should be doing. He even threatened the officer from the DoF that he would ban the officer from coming to this village. I was not happy and we fought. The case was referred to police and the court. I won the case and now he [the chief] is a bit quiet. ... But still I feel that if we are to implement new strategies at this beach, like the coordination with other beaches, then the chief has a final say. In the end, I can only implement what the chief has approved. He owns the beach; I only oversee the fisheries but this village has other issues too not just fish, so in that respect I have lesser power than him. Otherwise it may lead to a situation where the chief will say that I "have stepped on his head." Actually, I am sure that the situation is similar in other beaches.

What then would the BVC Chair's motivation be to maintain these rules? This question is pertinent because the BVC chairmanship is not remunerated by salary or a regular local contribution. Consequently, the BVC Chair has to go fishing just like the other fishers, in addition to doing the work connected to the chairmanship. We established that one incentive for the BVC Chairs is that they are occasionally invited for seminars by the DoF. Social reputation is, however, the major motivation for the BVC Chair, as often repeated in the interviews. Capacity to do the job of the BVC Chair effectively creates reputation, which in the background is backed by formal law through sections 7 and 8(1) of the FMCA. We see this backing mostly at work in conflict resolution and gear restriction.

\section{Power Relations Between the Village Chief and BVC Chair are the Key Dynamic}

The previous section has already made it clear that besides the BVC Chair, village chiefs are holding a powerful position in the Elephant Marsh Fishery; see also Lewins et al. (2014) 
and Russell and Dobson (2011). Our interviews with fishers, village chiefs, and BVC Chairs at the Elephant Marsh revealed four roles of chiefs in the small-scale fishery, as follows: (i) A BVC Chair cannot accept a new fisher without first asking for consent from the village chief. (ii) The BVC Chair cannot call for a meeting for fishers and other stakeholders such as fish traders without seeking approval from the village chief. (iii) The village chief has power to evict or fine (under customary law) a community member who is not abiding by village norms. (iv) The chief supports the BVC, for example, by safeguarding confiscated gear; as one chief put it, "When BVC Chairs confiscate illegal fishing gear, they pass it on to me for safe-keeping until the government officers come for handover. We work together well." It may therefore be asserted that by (dis)approving new fishers, the village chief helps to keep the membership of a fishing community in check.

We also established that the main motivation for the village chiefs is a weekly fish tribute that they receive from fishers (channeled through the BVC Chair) as part of their catch. Usually this amounts to some $5 \mathrm{~kg}$ of fish per beach per week with a monetary value of about US\$6/week. This amount would be higher if a village chief would allow many fishers at the beach but the fish catches would eventually decline as a result of an increased number of fishers and the tribute to the village chief would consequently decrease in value. Our analysis has also shown that if the village chief received his weekly fish tribute as scheduled, it was an indicator that the BVC Chairs and the fishers had trust in his or her leadership and legitimacy. In such trustworthy setups, the chief almost always supported the BVC leadership and there were usually no power struggles or conflicts with other stakeholders. In principle, this can only happen if the fish catches are good, which is probably a reason why the village chief was almost always supportive of the BVC Chair in villages that had good fish catches.

\section{The Department of Fisheries (DoF) and State-Based Sustainability Rules}

A point frequently voiced by respondents was that the DoF plays a role in influencing community attitudes and behavior toward fisheries management as stated by one fisher: "When they [DoF officers] come here, they teach us about good fishing practices but sometimes they confiscate illegal fishing gear." It is well known in Malawi that the government officers who are entrusted with the implementation of the state's fisheries management programs have low salaries (Anders 2009), in addition to facing numerous other challenges in getting the resources they need for their job. Our analysis therefore found it unreasonable to expect the government officers to sanction offenders of fisheries regulations or not be tempted to accept petty handouts in the form of fish or money. It was not surprising consequently to observe that those government officers often take no action against fishers who are using illegal gear. For example, in one case a fisheries assistant exhibited deliberate "closure of his eyes" and had this to say during a walk around a beach: "Yes indeed, we can see lots of juveniles in the catch here and on the fish drying racks, but that is OK because today is not my official visiting day for this beach."

Apart from the low salaries, it was also established that the extra challenges faced by DoF officers include the poor status of the roads leading to the beaches, lack of trust between government officers and village chiefs, high rates of illiteracy among fishers making it difficult to share information, inadequate resources for operations including lack of transport, and the differences in by-laws between BVCs, making it difficult to regulate 
because fishers move to beaches that have weaker rules, which often results in localized overfishing.

\section{The Central Government and Policies for Conflict Resolution}

The AiC analysis established a weak causal relationship between the central government and what actually happens in the Elephant Marsh fishery at present. For instance, DoF officers conduct surveys annually to check the legality of fishing gear and establish the total number of fishers. We particularly pay attention to the central government here because it is responsible for formulating policies that are deemed necessary for sustainable management of fisheries resources at national level.

The law governing fishing matters is contained in the FMCA, the Fisheries Conservation and Management Regulations (Government of Malawi 2000a), and the Fisheries Conservation and Management Rules (Government of Malawi 2000b). Under the FMCA, a BVC does not have power to suspend or cancel a fishing license granted by the DoF but may merely make a recommendation to the DoF to that effect. This provision reduces the de jure ability of the BVC chair to effectively manage fishers who are capable of paying the license fee to the DoF but fail to follow the bylaws at a fishing village. The status quo at the Elephant Marsh in which respected BVC chairs do have the de facto capacity to implement the bylaws is another proof of the disjoint between policy and localized reality.

\section{Toward an Empirically Based Management Institution: Modest, Local, and Amorphous}

The purpose of this section is to explore the principles of an institution that could help safeguard the sustainability of the Elephant Marsh fishery based on the empirical findings presented here. These findings are well suited for the institutional design goal, since the AiC framework has a causal orientation, which is paramount to the design of an effective solution (Anderies, Janssen, and Ostrom 2004).

Many institutional design theories and frameworks are available in the context of fisheries management. One is the set of empirically based institutional design rules of Ostrom (1990) and Cox, Arnold, and Tomás (2010). Another, more normative basis is the Institutional Analysis and Development (IAD) framework (Ostrom 1998b; Imperial and Yandle 2005), which focuses on a specific activity (action arena), the people who take part in the activity (actors), and their patterns of interaction that affect the resulting outcome (Whaley and Weatherhead 2014). The emphasis of the IAD framework on the patterns of interaction between actors is important in designing a relevant "action arena" for the Elephant Marsh Fishery. The IAD framework has been a reference point for later propositions such as that of Pahl-Wostl (2007), who proposes social learning for adaptive management. Adaptive capacity (the ability of the actors to live with changing external drivers such as market forces) has been found to be a critical determinant of institutional resilience (Aguilera et al. 2015). Indeed, if a new management system is designed for the Elephant Marsh Fishery, the ability of actors to live with change will be crucial for the resilience of the resultant institution. Our institutional design here is data based but pays close reference to the principles of Ostrom (1990), which were reviewed by Cox, Arnold, and Tomás (2010), and much akin to the "grounded theory" of Glaser and Strauss (2009). 
We initially put the general institutional theory and design frameworks between the brackets and let the data speak for themselves, without letting this voice be "colonized" (Cheney and Weston 1999) by the conceptual classifications and normative criteria of the theories and frameworks. Thereafter we relate our data-based propositions with design rules of Ostrom (1990) and Cox, Arnold, and Tomás (2010) such as "nested enterprises" (rules at each of the fishing villages at the Elephant Marsh should be nested within the rules at the scale of the whole fishery), "collective choice arrangements" (the majority of actors at the Elephant Marsh Fishery should have the autonomy to formulate rules), "congruence with local conditions" (locally crafted fishing rules should be present), "monitoring" (BVCs with support from other actors should have the responsibility to monitor the resource), "graduated sanctions" (there should be application of varied sanctions to offenders depending on severity and frequency of violation), and "conflict resolution mechanism" (locally acceptable adjudication should be available within the fishing community at Elephant Marsh). By nature, theories and frameworks easily resonate with the vision of good institutions in that both aim to be coherent, logical, and generic. Blending the "grounded theory" way with the design principles of design rules of Ostrom (1990) and Cox, Arnold, and Tomás (2010) may be not only appropriate for the Elephant Marsh Fishery but also an experiment of more general value for institutional science; it invites us out of the box, discovering that pillars for good institutions may sometimes also, in a way and to some extent, be of low cost, purely locally crafted, and amorphous (internally unstructured).

\section{Pillar 1: A Low-Cost Institution Built for Growth and Adaptation}

Fish catch data at the Elephant Marsh Fishery are scarce but signs are that real overfishing does take place locally in the marsh's mosaic, as indicated by the temporary migration of fishers to beaches where they get higher catches and these beaches' BVC Chairs taking action by crafting local fishing rules of closed seasons and regulated gear. The "graduated sanctions" contained in the operational rules are now seen to slowly grow "upward" as "collective choice arrangements" in two senses: spatially from a local to a supralocal level through interbeach coordination, and institutionally from informal personal rule to formal rule of (local) law. In congruence with the local conditions, virtually all of our respondents agreed that some sort of really supralocal institution, on the clearly defined boundaries of the Elephant Marsh, could be helpful. The question then becomes: helpful to do what? What should be the mandate and "action arena" of such an institution that could link up with currently felt needs? From our data, four functions come to mind: (i) strengthening of the ongoing process of inter-BVC coordination, (ii) implementation of a simple, peoplebased marsh-wide monitoring system, integrating the locally available informal data on catches and catch per unit effort (CPUE), (iii) discussing a self-organized but yet more cost-effective relationship with the government (Ostrom's 1990 minimum recognition of rights to organize), which could, for instance, motivate fisheries officers to "open their eyes," and (iv) informally exploring long-term management strategies using hypothetical scenarios, for example, rising population and climate change. These four tasks would create an adaptive learning institution preparing itself for growth and action if needed, without requiring costly administrative overload. Basically, the current village-level institutions are good enough to only require a yearly marsh-wide coordination meeting of, say, 2 days. The necessity of such a low-cost institution does not require justification at the local level 
and could be locally funded. Expressing its modest mandate, it could, for instance, be called the Annual Elephant Marsh Fisheries Meeting — not "Board" or "Authority" or anything of that weight yet.

\section{Pillar 2: A Purely Locally Based "Nested Enterprise"}

As we have seen in the third section, rules that work at the Elephant Marsh fishery are both locally crafted and locally enforced. Consequently, the weak presence of the state and national fisheries policies in the Elephant Marsh may be seen as a benign rather than a problematic circumstance. Indeed, the semiquantitative analyses of Kosamu (2014; 2015) have shown that on both the level of the Elephant Marsh and that of 17 other cases in developing countries, strong local institutions enhance sustainability while any state interference, whether imposing rules in state-based management or negotiating rules in comanagement, results in a breakdown of sustainability-enhancing rules. The analysis of this article has shown why this may be so. Reputation is both the key motivation and the key capacity (power) of the BVC Chairs and the village chiefs. Why would they continue to be motivated if they cannot be their "own man" anymore, being degraded to an implementer of exotic conflict resolution mechanisms or policeman of external rules? Why would fishers listen to such people, given that real state power (courts, fines) is in fact far away? This approach can help in understanding how a supralocal institution, leaving local motivations and power intact, may create desirable outcomes. This leads to a point where we can visualize a marsh-wide institution as a purely locally based "nested enterprise" sensu Ostrom (1990), crafted and governed by the local committees with the same power-sharing structure as discussed in the third section. According to Kolding, Béné, and Bavinck (2014), when such self-governing systems are established, they enjoy greater local legitimacy, particularly in weak political systems (as is the case in Malawi and most developing countries), and therefore stand a better chance of success.

\section{Pillar 3: An Internally Amorphous Institution}

As highlighted, the power interaction between the BVC Chairs and their village chiefs is the key dynamic determining the fate of the fishery at the local level. If they support each other's reputation, the beach will be well managed. However, reputation, being a volatile capital, is vulnerable to any emergent conflicts, which can easily result in breakdown of rules and subsequent overfishing. It may be noted that at the village level, the relationship between a BVC Chair and a village chief, though framed in general cultural traditions and metaphors, is primarily personal and not captured in the legal framework or administrative logic. It would appear wise to maintain this principle at the supralocal level of the marshwide institution. Any logical task division between the two groups (e.g., as decision makers vs. advisors, decision makers vs. implementers, politics vs. administration) would frame the two roles as opposed and/or subordinate to each other, and subsequently bring disunity and tensions down to the local level. Therefore, counterintuitive as it may seem, the marsh-wide institution should be left internally unstructured, with village chiefs and BVC Chairs included without formal specification of their roles to give a chance for self-organization. In so doing, the institution does not force Western formats of democracy on the local system, which can continue with its own style (Nkhata, Breen, and Abacar 2009) of 
mixing mandates (hereditary, elected, and legal) with the power mechanisms of reputation. This leaves room, for instance, for lessons to be interpreted and transmitted from chiefs who successfully manage the power differential with their BVCs and therewith create well-managed beaches. In the case of the Elephant Marsh, where all of the four types of power relations distinguished by Agrawal and Ribot (1999) are centralized with the chiefs, an internally amorphous institution that reproduces the local power setup will ensure that the chiefs' opinions will tend to prevail in the end, but not without due deliberation at the level of the fishing community. This does not differ much from the principle of the final "primacy of politics" (political power being key in reshaping community needs and the economy) in the Western trias politica (Kickert 2001).

\section{Conclusion}

As we have seen, an actor-based multilevel analysis of rules and other mechanisms prevailing in a fishery can help much in designing a cost-effective institution for the near future. For the design of longer term institutional options, the assumptions underlying the actors-based method (Action-in-Context in our case) become weaker, for example, because new types of actors may move in making the BVCs dysfunctional or because actor capacities and motivations become more intertwined. This then necessitates a stronger blend and reliance on both theoretically driven institutional frameworks and a flexible process of institutional development guided by an adaptive, learning organization. It is our conviction that a sustainable management system for Elephant Marsh Fishery relies on three pillars: a low-cost, weak institution built for growth and adaptation; a purely locally based "nested enterprise"; and an internally amorphous institution. In so doing, we hope to have unveiled a management design for the Elephant Marsh fishery specifically and a style of thinking that may be fruitful for institutional science in general.

\section{References}

Agrawal, A., and J. Ribot. 1999. Accountability in decentralization: A framework with South Asian and West African cases. The Journal of Developing Areas 33 (4):473-502.

Aguilera, S. E., J. Cole, E. M. Finkbeiner, E. Le Cornu, N. C. Ban, M. H. Carr, J. E. Cinner, L. B. Crowder, S. Gelcich, C. C. Hicks, and J. N. Kittinger. 2015. Managing small-scale commercial fisheries for adaptive capacity: Insights from dynamic social-ecological drivers of change in Monterey Bay. PloS ONE 10 (3):e0118992. doi:10.1371/journal.pone.0118992

Anderies, J. M., M. A. Janssen, and E. Ostrom. 2004. A framework to analyze the robustness of social-ecological systems from an institutional perspective. Ecology and Society 9 (1):18.

Anders, G. 2009. Like chameleons: Civil servants and corruption in Malawi. Governance of Daily Life in Africa 19:119-42. doi:10.1163/ej.9789004171282.i-347.33

Bavinck, M. 1996. Fisher regulations along the Coromandel Coast: A case of collective control of common pool resources. Marine Policy 20 (6):475-82. doi:10.1016/s0308-597x(96)00039-5

Bavinck, M. 2005. Understanding fisheries conflicts in the South-A legal pluralist perspective. Society \& Natural Resources 18 (9):805-20. doi:10.1080/08941920500205491

Bodin, Ö., and B. I. Crona. 2009. The role of social networks in natural resource governance: What relational patterns make a difference? Global Environmental Change 19 (3):366-74. doi:10.1016/ j.gloenvcha.2009.05.002

Brondizio, E. S., E. Ostrom, and O. R. Young. 2009. Connectivity and the governance of multilevel social-ecological systems: The role of social capital. Annual Review of Environment and Resources 34:253-78. doi:10.1146/annurev.environ.020708.100707 
Cheney, J., and A. Weston. 1999. Environmental ethics as environmental etiquette. Environmental Ethics 21 (2):115-34. doi:10.5840/enviroethics199921226

Cleaver, F. 2002. Reinventing institutions: Bricolage and the social embeddedness of natural resource management. The European Journal of Development Research 14 (2):11-30. doi:10.1080/ 714000425

Cox, M., G. Arnold, and S. V. Tomás. 2010. A review of design principles for community-based natural resource management. Ecology and Society 15 (4):38 (1-23).

Crona, B., and Ö. Bodin. 2010. Power asymmetries in small-scale fisheries: A barrier to governance transformability. Ecology and Society 15 (4):32.

De Groot W. T. 1992. Environmental science theory: Concepts and methods in a one-world, problemoriented paradigm. Amsterdam, The Netherlands: Elsevier Science.

Elster, J. 1989. Nuts and bolts for the social sciences. Cambridge, UK: Cambridge University Press.

Glaser, B. G., and A. L. Strauss. 2009. The discovery of grounded theory: Strategies for qualitative research. New Brunswick, NJ: Transaction.

Glaser, M. 2006. The social dimension in ecosystem management: Strengths and weaknesses of human-nature mind maps. Human Ecology Review 13 (2):122.

Government of Malawi. 1968. Trustees incorporation act. Zomba, Malawi: Government Printer.

Government of Malawi. 1997. Fisheries conservation and management act. Lilongwe, Malawi: Government Printer.

Government of Malawi. 2000a. Fisheries conservation and management regulations. Lilongwe, Malawi: Government Printer.

Government of Malawi. 2000b. Fisheries conservation and management rules. Lilongwe, Malawi: Government Printer.

Government of Malawi. 2001. National fisheries and aquaculture policy. Lilongwe, Malawi: Government Malawi.

Hobbes, M., S. I. Stalpers, J. Kooijman, T. T. T. Le, K. C. Trinh, and T. A. D. Phan. 2007. Material flows in a social context: A Vietnamese case study combining the materials flow analysis and action-in-context frameworks. Journal of Industrial Ecology 11 (1):141-59. doi:10.1162/ jiec.2007.1049

Imperial, M. T., and T. Yandle. 2005. Taking institutions seriously: Using the IAD framework to analyse fisheries policy. Society \& Natural Resources 18:493-509. doi:10.1080/08941920590947922

Kickert, W. J. 2001. Public management of hybrid organizations: Governance of quasi-autonomous executive agencies. International Public Management Journal 4 (2):135-50. doi:10.1016/s10967494(01)00049-6

Kolding, J., C. Béné, and M. Bavinck. 2014. Small-scale fisheries - Importance, vulnerability, and deficient knowledge. In Governance for marine fisheries and biodiversity conservation: Interaction and coevolution, ed. S. Garcia, J. Rice, and A. Charles 317-31. Chichester, West Sussex, UK: John Wiley \& Sons.

Kosamu, I. B. M. 2014. Conditions for sustainability of the Elephant Marsh fishery in Malawi. Sustainability 6 (7):4010-27. doi:10.3390/su6074010

Kosamu, I. B. M. 2015. Conditions for sustainability of small-scale fisheries in developing countries. Fisheries Research 161:365-73. doi:10.1016/j.fishres.2014.09.002

Kosamu, I. B. M., W. T. de Groot, P. S. Kambewa, and G. R. de Snoo. 2012. Institutions and ecosystem-based development potentials of the Elephant Marsh, Malawi. Sustainability 4 (12): 3326-45. doi:10.3390/su4123326

Kostova, T., and K. Roth. 2003. Social capital in multinational corporations and a micromacro model of its formation. Academy of Management Review 28 (2):297-317. doi:10.2307/ 30040714

Latour, B. 2005. Reassembling the social: An introduction to actor-network-theory. New York, NY: Oxford University Press.

Lewins, R., C. Béné, M. O. Baba, E. Belal, S. Donda, A. M. Lamine, A. Makadossou, N. A. M. Tahir, A. E. Neiland, F. Njaya, S. Ovie, and A. Raji. (2014). African inland fisheries: Experiences with co-management and policies of decentralization. Society \& Natural Resources 27 (4):405-20. doi:10.1080/08941920.2013.861564 
National Statistics Office (NSO). 2008. Malawi Population and Housing Census Report. Zomba, Malawi.

Nkhata, B. A., C. M. Breen, and A. Abacar. 2009. Social capital, community-based governance and resilience in an African artisanal river fishery. Water SA 35 (1):45-53.

Nunan, F. 2010. Mobility and fisher folk livelihoods on Lake Victoria: Implications for vulnerability and risk. Geoforum 41 (5):776-85. doi:10.1016/j.geoforum.2010.04.009

Ostrom, E. 1990. Governing the commons: The evolution of institutions for collective action. Cambridge, UK: Cambridge University Press.

Ostrom, E. 1992. Crafting institutions for self-governing irrigation systems. San Francisco, CA: Institute for Contemporary Studies.

Ostrom, E. 1998a. A behavioral approach to the rational choice theory of collective action: Presidential address, American Political Science Association, 1997. American Political Science Review 92 (1):1-22. doi:10.2307/2585925

Ostrom, E. 1998b. The institutional analysis and development approach. In Designing institutions for environmental and resource management, ed. E. Tusak-Loehman and D. M. Kilgur 68-90. Northampton, MA: Edward Elgar.

Pahl-Wostl, C. 2007. Transitions towards adaptive management of water facing climate and global change. Water Resources Management 21 (1):49-62. doi:10.1007/s11269-006-9040-4

Russell, A. J. M., and T. Dobson. 2011. Chiefs as critical partners for decentralized governance of fisheries: An analysis of co-management case studies in Malawi. Society \& Natural Resources 24:734-50. doi:10.1080/08941920.2010.501432

Schwartz, S. H., J. Cieciuch, M. Vecchione, E. Davidov, R. Fischer, C. Beierlein, A. Ramos, M. Verkasalo, J. Lönnqvist, K. Demirutku, O. Dirilen-Gumus, and M. Konty. 2012. Refining the theory of basic individual values. Journal of Personality and Social Psychology 103 (4):663-88. doi:10.1037/a0029393

Simon, H., D. W. Smithburg, and V. A. Thompson. 1958. Public administration. New York, NY: Alfred A. Knopf.

Song, A. M., and R. Chuenpagdee. 2011. Conservation principle: A normative imperative in addressing illegal fishing in Lake Malawi. MAST 10 (1):5-30.

Vayda, A. P. 1983. Progressive contextualization: Methods for research in human ecology. Human Ecology 11 (3):265-81. doi:10.1007/bf00891376

Vayda, A. P., and B. B. Walters. 1999. Against political ecology. Human Ecology 27 (1):167-79.

Whaley, L., and E. K. Weatherhead. 2014. An integrated approach to analyzing (adaptive) comanagement using the "politicized" IAD framework. Ecology and Society 19 (1):10. doi:10.5751/es-06177-190110

World Bank. 2010. The Zambezi River basin, A multi-sector investment opportunities analysis, State of the Basin; Report 3. Washington, DC: World Bank.

World Bank. 2015. Ending extreme poverty and sharing prosperity: Progress and policies. Policy Research Note PRN/15/03. Washington, DC: World Bank. 